\title{
KORELASI ANTARA GAYA BELAJAR SISWA, KONDISI EKONOMI KELUARGA DAN KEDISIPLINAN SISWA DENGAN PRESTASI BELAJAR FISIKA
}

\author{
Dhien Astrini \\ Program Studi Pendidikan Fisika, Universitas Sarjanawiyata Tamansiswa \\ Magister Penelitian dan Evaluasi Pendidikan, Universitas Negeri Yogyakarta \\ Dosen Program Studi Sistem Informasi, STMIK PPKIA Tarakanita Rahmawati \\ email: dhienastrini@gmail.com
}

\section{Abstrak}

Penelitian ini bertujuan untuk mencari korelasi antara gaya belajar siswa, kondisi ekonomi keluarga, kedisiplinan siswa dengan prestasi belajar fisika kelas XI SMA Se-Kecamatan Ngampilan. Jenis penelitian ini adalah deskriptif korelatif. Populasi dalam penelitian ini adalah siswa kelas XI sebanyak 114 siswa. Teknik pengambilan data menggunakan Cluster Random Sampling dan penentuan sampel menggunakan tabel Krejcie Morgan sebanyak 86 responden. Teknik pengumpulan data menggunakan teknik tes dan teknik angket. Validitas instrumen dengan menggunakan korelasi product moment, dan reliabilitas instrumen menggunakan rumus KR-20 dan rumus alpha cronbach. Hasil penelitian menunjukan bahwa ada korelasi yang positif dan signifikan antara gaya belajar siswa, kondisi ekonomi keluarga dan kedisiplinan siswa dengan prestasi belajar fisika. Koefisien determinasi $\mathrm{R}^{2}=$ 0,487. Sumbangan efektif dari ketiga prediktor sebesar $48,707 \%$ dengan gaya belajar sebesar 10,488\%, kondisi ekonomi keluarga sebesar 5,750\% dan kedisiplinan siswa sebesar 32,469\%.

Kata kunci: Gaya belajar, Kondisi ekonomi, Kedisiplinan siswa

\section{Abstrack}

This research was to know correlation between style learn student, condition of family economics, student discipline and achievement learn student of physics class XI in senior high school in district of Ngampilan. The kind of this research is corelational description. The population in research is student class XI about 114 student. Technique intake of sampel with Cluster Random Sampling and the population of sampel according to tables of Krejcie and Morgan to the number of sampel 86 responder. The data were take used quisioner likert and technique of tes. Validity instrument test with correlation formula of Product Moment, while test of reliabilitas with formula of KR-20 and formula of Alpha Cronbach. The result of research show there correlation which are positive and very significant between style learn student, condition of family economics, student discipline and achievement learn physics. Coefficient value of determinasi $\mathrm{R}^{2}=0,487$. Effective contribution of third prediktor equal to $48,707 \%$ what consist of style learn student equal to $10,488 \%$, condition of family economics equal to $5,750 \%$ and student discipline equal to $32,469 \%$. 


\section{Keywords: Style learn, Condition Of Economics, Student Discipline}

\section{PENDAHULUAN}

Setiap manusia membutuhkan pendidikan dan pembelajaran. Pendidikan dapat diberikan sejak dini kepada setiap individu yang tumbuh mulai dari anak-anak, remaja, dan dewasa. Mereka memiliki pengetahuan yang semakin berkembang seiring dengan pertumbuhannya. Sehingga, melalui pendidikan setiap individu memiliki prestasi belajar. Menurut Zainal Arifin (2012: 12) kata "Prestasi berasal dari bahasa Belanda yaitu Prestatie kemudian dalam bahasa Indonesia menjadi prestasi yang berarti hasil usaha". Prestasi belajar fisika di SMA Kelas XI IPA saat ini semakin mengalami penurunan. Banyak siswa yang kurang bersungguh-sungguh dalam mempelajari materi fisika yang diajarkan oleh guru. Kebanyakan dari mereka enggan untuk menanyakan kesulitan yang dihadapi dalam menyelesaikan persoalan fisika. Akibatnya, mereka mengalami kesulitan dalam menyelesaikan soal yang diberikan.

Prestasi belajar sangat dipengaruhi oleh berbagai faktor. Salah satu faktor yang mempengaruhi keberhasilan dalam belajar adalah gaya belajar. Gaya belajar bukanlah sesuatu yang statis. Gaya belajar dapat berubah tergantung pada aktifitas belajar atau perubahan pengalaman. Sebagian peserta didik mungkin menggunakan gaya belajar berbeda dalam situasi dan kondisi yang tidak sama. Suatu gaya belajar mungkin lebih efektif atau kurang efektif dalam suatu situasi tertentu. (Nini Subini, 2012:31). Guru dapat mengidentifikasi kecenderungan gaya belajar siswa. Hal ini sangat bermanfaat untuk mengembangkan proses belajar mengajar. Namun, banyak guru yang belum memperhatikan aspek gaya belajar para siswa sehingga penyampaian materi dalam proses pembelajaran fisika masih monoton. Banyak guru yang belum memaksimalkan metode pembelajaran yang digunakan, cenderung hanya menggunakan satu metode. Sehingga gaya mengajar guru belum sesuai dengan gaya belajar siswa.

Menurut Sundayana, R (2016: 76) gaya belajar merupakan kebiasaan siswa dalam memproses bagaimana menyerap informasi, pengalaman, serta kebiasaan siswa dalam memperlakukan pengalaman yang dimilikinya. Jika siswa akrab dengan gaya belajarnya sendiri, maka siswa dapat mengambil langkah-langkah penting untuk membantu diri siswa belajar lebih cepat dan lebih mudah, sehingga hal ini akan mendukung pula terhadap apa yang menjadi tujuan dari pembelajaran.

Adapun macam-macam gaya belajar adalah sebagai berikut. (Bobbi De Porter, 2002: 114)

1. Gaya Belajar Auditorial

Orang-orang auditorial lebih suka mendengarkan materinya dan kadang-kadang kehilangan urutannya jika mereka mencoba mencatat materinya selama presentasi berlangsung. Ciri-ciri dalam gaya belajar auditorial, antara lain:
a) mudah terganggu oleh keributan
b) belajar dengan mendengarkan dan mengingat apa yang didiskusikan daripada yang dilihat
c) dapat mengulangi kembali dan menirukan nada, birama dan warna suara
d) lebih suka musik daripada seni 
e) berbicara dengan irama terpola

f) lebih pandai mengeja dengan keras daripada menuliskannya

2. Gaya Belajar Visual

Orang-orang visual lebih suka membaca makalah dan memperhatikan ilustrasi yang ditempelkan pembicara di papan tulis. Ciri-ciri dalam gaya belajar visual, antara lain:

a) rapi dan teratur

b) berbicara dengan cepat

c) lebih suka membaca daripada dibacakan

d) biasanya tidak terganggu oleh keributan

e) pembaca cepat dan tekun

f) mengingat apa yang dilihat daripada apa yang didengar

3. Gaya Belajar Kinestetik

Pelajar kinestetik lebih baik dalam aktivitas bergerak dan interaksi kelompok.Adapun ciri-ciri perilaku pelajar kinestetik adalah sebagai berikut.

a) berbicara dengan perlahan

b) menanggapi perhatian fisik

c) menyentuh orang untuk mendapat perhatian mereka

d) tidak dapat duduk diam dalam waktu lama

e) banyak menggunakan isyarat tubuh

Nana Syaodih Sukmadinata (2003: 48) mengungkapkan bahwa Perkembangan dan perilaku individu juga dipengaruhi oleh lingkungan ekonomi, yaitu lingkungan yang berkenaan dengan cara-cara manusia mengatur dan memenuhi kebutuhan hidupnya, terutama kebutuhan akan sandang, pangan serta papan. Kondisi dari lingkungan ekonomi yang ada serta tantangan-tantangan yang dihadapi dalam memenuhi kebutuhan ekonomi, akan sangat berpengaruh terhadap perkembangan dan perilaku individu yang berada dalam lingkungan tersebut.

Lingkungan pembelajaran yang sesuai dengan gaya belajar siswa belum tercipta secara optimal. Hal ini ditandai dengan adanya beberapa alat di laboratorium yang sudah tidak berfungsi dengan baik. Selain itu, lokasi sekolah berdekatan dengan bangunan sekolah lain dan berhadapan dengan jalan besar sehingga suasana pembelajaran menjadi kurang kondusif. Kondisi ekonomi keluarga dan kedisiplinan siswa juga perlu diperhatikan yang dapat meningkatkan prestasi belajar fisika. Kondisi ekonomi keluarga merupakan salah satu faktor penentu dalam keberhasilan belajar siswa. Menurut Desmita (2012: 219) "Keluarga merupakan unit sosial yang terkecil yang memiliki peranan penting dan menjadi dasar bagi perkembangan psikososial anak dalam konteks sosial yang lebih luas". Keluarga bertanggung jawab menyediakan dana untuk kebutuhan pendidikan anak.

Keluarga yang kondisi ekonominya tinggi tidak akan banyak mengalami kesulitan dalam memenuhi segala kebutuhan sekolah yang diperlukan anak. Anak dapat belajar dengan baik menggunakan fasilitas yang diberikan keluarganya. Berbeda dengan keluarga yang kondisi ekonominya pas-pasan atau rendah cenderung mengalami kesulitan dalam memenuhi kebutuhan anak terutama dalam hal fasilitas yang mendukung kegiatan belajar sekolah akibatnya terjadi kesulitan belajar pada anak dan menghambat proses 
pembelajaran anak. Dengan demikian, kondisi ekonomi keluarga sangat mempengaruhi prestasi belajar siswa di sekolah.

Menurut Slameto (2003: 63) "Keadaaan ekonomi keluarga erat hubungannya dengan belajar anak, anak yang sedang belajar selain harus terpenuhi kebutuhan pokoknya, misal makan, pakaian, perlindungan kesehatan dan lain-lain, juga membutuhkan fasilitas belajar seperti ruang bekajar, meja, kursi, penerangan, alat tulis-menulis, buku dan lain-lain". Kondisi ekonomi keluarga bukan saja akan mempengaruhi gizi dan kesehatan anak, tetapi juga akan mempengaruhi kesempatan dan mutu belajar anak. Kondisi ekonomi keluarga yang baik akan memberikan kesempatan belajar yang lebih banyak dan lebih tinggi dengan fasilitas belajar yang lebih baik dibandingkan dengan kondisi ekonomi yang kurang baik. (Nana Syaodih Sukmadinata, 2003: 48).

Seorang anak jika kurang mendapat dukungan dalam hal sarana dan prasarana yang menunjang kebutuhan belajarnya maka dapat menghambat keinginan anak untuk belajar. Akibatnya dapat berpengaruh pada kedisiplinan anak di sekolah. Menurut Mulyasa (2008: 191) "Disiplin adalah suatu keadaan tertib, ketika orang-orang yang tergabung dalam suatu sistem tunduk pada peraturan-peraturan yang ada dengan senang hati". Kedisiplinan erat hubungannya dengan kerajinan siswa dalam mengikuti aturan yang berlaku dan juga dalam meraih prestasi belajar di sekolah. Kedisiplinan siswa di sekolah saat ini masih banyak dilanggar oleh siswa.

Menurut Nini Subini (2012: 98) Jika ada anak yang tidak mengerjakan PR dibiarkan saja, tanpa diberi hukuman, selamanya jika ada tugas rumah ia tidak akan mengerjakan. Berbeda dengan guru yang memberi sanksi pada anak yang lupa mengerjakan tugasnya, anak akan berusaha mengerjakan apa yang menjadi pekerjaan rumahnya. Kedisiplinan itu sangat penting untuk perkembangan siswa demi masa depan yang cerah. Karena dengan kedisiplinan, siswa akan termotivasi untuk mencapai apa yang siswa inginkan dan citacitakan (Wirantasa, U. 2017: 85).

Masalah kedisiplinan siswa di sekolah juga penting bagi kemajuan sekolah. Di sekolah yang tertib akan selalu menciptakan proses pembelajaran yang baik. Sebaliknya, pada sekolah yang kurang tertib kondisinya akan jauh berbeda. Hal ini perlu dilakukan usaha keras baik dari dalam individu, orang tua maupun pihak sekolah untuk mengubahnya. Menurut Conny R. Semiawan (2008: 92) "Tujuan disiplin bukan untuk melarang kebebasan atau mengadakan penekanan, melainkan memberikan kebebasan dalam batas kemampuannya untuk ia kelola".

Disiplin juga dapat mengandung arti adanya kesediaan untuk mematuhi peraturanperaturan yang berlaku. Kepatuhan disini bukan hanya karena adanya tekanan-tekanan dari luar, melainkan kepatuhan yang didasari oleh adanya kesadaran tentang nilai dan pentingnya peraturan-peraturan (Haryono. S, 2016: 264). Sekolah harus bisa meyakinkan pada para siswa bahwa perilaku baik dan prestasi belajar yang cemerlang hanya bisa diraih dengan kedisiplinan tinggi para siswa di sekolah. Oleh karena itu, pihak sekolah hendaknya menegakkan budaya disiplin kepada para siswa. Dengan demikian, prestasi belajar siswa semakin membanggakan dan mampu meningkatkan nama baik sekolah serta diharapkan prestasi belajar siswa dapat optimal.

Pendidik harus terus menerus berupaya mencari terobosan-terobosan baru salah satunya dengan mengadakan penelitian. Penelitian tentang hubungan faktor ekstern dan 
intern sangat penting untuk dikembangkan, sebab dengan demikian seorang pendidik sekaligus orang tua dapat mengetahui tentang hal-hal apa saja yang dapat dilakukan untuk memperbaiki kualitas belajar anak-anaknya (Effendi: 2018). Dengan mengetahui tentang pentingnya hal tersebut, maka orang tua bersama-sama dengan pendidik akan terus menerus berupaya agar pembelajaran akan lebih baik. Oleh karena itu, penelitian ini bertujuan untuk mengetahui seberapa besar tingkat korelasi antara gaya belajar siswa, kondisi ekonomi keluarga dan kedisplinan siswa dengan prestasi belajar fisika.

\section{METODE}

Jenis penelitian ini adalah penelitian deskriptif korelasional yang bertujuan untuk mencari korelasi antar variabel bebas dengan variabel bebas, dan antar variabel bebas dengan variabel terikat yang bersifat ex post facto. Penelitian ini dilaksanakan di SMA Kelas XI Kecamatan Ngampilan Kota Yogyakarta. Jumlah sampel responden pada penelitian ini sebanyak 86 orang. Teknik pengumpulan data dalam penelitian ini menggunakan teknik tes untuk data tentang prestasi belajar fisika yang terdiri dari 30 soal dan teknik angket untuk data tentang gaya belajar siswa, kondisi ekonomi keluarga dan kedisiplinan sekolah terdiri dari 30 item.

Teknik analisis data yang digunakan analisis deskriptif yang perlu dicari terlebih dahulu skor terendah, skor tertinggi, rata-rata, simpangan baku dari setiap variabel kemudian dibandingkan dengan kurva normal ideal (Anas Sudijono, 2012: 329). Kemudian uji persyaratan analisis yaitu meliputi uji normalitas sebaran menggunakan rumus chikuadrat (Sugiyono, 2010:241) dan uji linieritas hubungan dengan menggunakan uji $\mathrm{F}$ (Suharsimi Arikunto, 2010: 367). Uji Hipotesis yaitu Hipotesis mayor menggunakan teknik regresi ganda 3 prediktor (Sugiyono, 2007: 257) untuk menguji signifikansi digunakan rumus F regresi (Sugiyono, 2007: 259) dan Hipotesis Minor menggunakan analisis korelasi parsial (Sugiyono, 2010: 268) serta untuk menguji signifikansi digunakan uji-t (Sugiyono, 2010: 259).

\section{HASIL DAN PEMBAHASAN}

\section{Hasil Uji Coba Instrumen}

a. Uji Validitas

1) Angket Gaya belajar siswa dari 30 butir, sahih 29 butir, gugur 1 butir, yaitu item 30.

2) Angket Kondisi Ekonomi Keluarga dari 30 butir, sahih 28 butir, gugur 2 butir, yaitu item 3 dan 26.

3) Angket Kedisiplinan Siswa dari 30 butir, sahih 27 butir, gugur 3 butir yaitu item 7, 17 dan 21.

4) Tes Prestasi Belajar Fisika dari 30 butir, sahih 27 butir, gugur 3 butir yaitu item 10, 26 dan 27. 
b. Uji Reliabilitas Tes

Uji reliabilitas tes menggunakan rumus KR-20 diperoleh tes prestasi belajar fisika dengan nilai $r_{t t}=0,835$ dengan $p=0,000$. Karena $p<0,05$ maka instrumen prestasi belajar fisika dinyatakan reliabel.

c. Uji Reliabilitas Angket

Uji reliabilitas angket menggunakan rumus Alpha Cronbach diperoleh:

1) Angket Gaya belajar siswa diperoleh $r_{t t}=0,851$ dengan $p=0,000$. Karena $p<$ 0,05 maka instrumen angket gaya belajar siswa dinyatakan reliabel.

2) Angket Kondisi ekonomi keluarga diperoleh $r_{t t}=0,873$ dengan $p=0,000$. Karena $\mathrm{p}<0,05$ maka instrumen angket kondisi ekonomi keluarga dinyatakan reliabel.

3) Angket Kedisiplinan siswa diperoleh $r_{t t}=0,900$ dengan $p=0,000$. Karena $p<$ 0,05 maka instrumen angket Kedisiplinan siswa dinyatakan reliabel.

2. Deskripsi Data Penelitian

a. Gaya Belajar Siswa $\left(\mathrm{X}_{1}\right)$

Data mengenai gaya belajar siswa diperoleh dengan menjumlahkan skor angket. Angket gaya belajar siswa yang terdiri dari 30 butir dari hasil penelitian diperoleh butir yang sahih ada 29 butir dan yang gugur ada 1 butir. Skala penilaian tertinggi 5 dan terendah 1 diperoleh sebagai berikut. Skor maksimal ideal $=29 \times 5=$ 145 , Skor minimal ideal $=29 \times 1=29, \mathrm{M}_{\text {ideal }}=0,5(145+29)=87, \mathrm{SD}_{\text {ideal }}=0,167$ $(145-29)=19,4$. Berdasarkan nilai rata-rata ideal dan standar deviasi ideal diperoleh kriteria umum kurva normalnya sebagai berikut.

$$
\begin{aligned}
116,10<\bar{X} \leq 145,00 & =\text { sangat tinggi } \\
96,70<\bar{X} \leq 116,10 & =\text { tinggi } \\
77,30<\bar{X} \leq 96,70 & =\text { sedang } \\
57,90<\bar{X} \leq 77,30 & =\text { rendah } \\
29,00<\bar{X} \leq 57,90 & =\text { sangat rendah }
\end{aligned}
$$

Hasil penelitian diperoleh skor tertinggi 133, skor terendah 59, simpangan baku 11,08 dan rata-rata skor gaya belajar siswa sebesar 98,13 berada dalam interval $96,70<\overline{\mathrm{X}} \leq 116,10$. Dengan demikin, dapat disimpulkan bahwa kecenderungan gaya belajar siswa kelas XI SMA se-Kecamatan Ngampilan termasuk kategori tinggi.

\section{b. Kondisi Ekonomi Keluarga $\left(\mathrm{X}_{2}\right)$}

Data mengenai kondisi ekonomi keluarga diperoleh dengan menjumlahkan skor angket. Angket kondisi ekonomi keluarga yang terdiri dari 30 butir dari hasil penelitian diperoleh butir yang sahih ada 28 butir dan yang gugur ada 2 butir. Skala penilaian tertinggi 5 dan terendah 1 diperoleh Skor maksimal ideal $=28 \times 5=140$, Skor minimal ideal $=28 \times 1=28, \mathrm{M}_{\text {ideal }}=0,5(140+28)=84, \mathrm{SD}_{\text {ideal }}=0,167(140-$ $28)=18,7$. Berdasarkan nilai rata-rata ideal dan standar deviasi ideal diperoleh kriteria umum kurva normalnya sebagai berikut.

$$
\begin{aligned}
112,05<\bar{X} \leq 140,00 & =\text { sangat tinggi } \\
93,35<\bar{X} \leq 112,05 & =\text { tinggi }
\end{aligned}
$$




$$
\begin{aligned}
& 74,65<\overline{\mathrm{X}} \leq 93,35=\text { sedang } \\
& 55,95<\overline{\mathrm{X}} \leq 74,65=\text { rendah } \\
& 28,00<\overline{\mathrm{X}} \leq 55,95=\text { sangat rendah }
\end{aligned}
$$

Hasil penelitian diperoleh skor tertinggi 112, skor terendah 48, simpangan baku 12,10 dan rata-rata skor kondisi ekonomi keluarga sebesar 78,42 berada dalam interval $74,65<\bar{X} \leq 93,35$. Dengan demikian, dapat disimpulkan bahwa kecenderungan kondisi ekonomi keluarga kelas XI SMA se-Kecamatan Ngampilan termasuk kategori sedang.

c. Kedisiplinan Siswa $\left(\mathrm{X}_{3}\right)$

Data mengenai kedisiplinan siswa diperoleh dengan menjumlahkan skor angket. Angket kedisiplinan siswa yang terdiri dari 30 butir dari hasil penelitian diperoleh butir yang sahih ada 27 butir dan yang gugur ada 3 butir. Skala penilaian tertinggi 5 dan terendah 1 diperoleh Skor maksimal ideal $=27$ x $5=135$, Skor minimal ideal $=27 \times 1=27 . \mathrm{M}_{\text {ideal }}=0,5(135+27)=81, \mathrm{SD}_{\text {ideal }}=0,167=0,167(135$ $-27)=18$. Berdasarkan nilai rata-rata ideal dan standar deviasi ideal diperoleh kriteria umum kurva normalnya sebagai berikut.

$$
\begin{gathered}
108,00<\bar{X} \leq 135,00=\text { sangat tinggi } \\
90,00<\bar{X} \leq 108,00=\text { tinggi } \\
72,00<\bar{X} \leq 90,00=\text { sedang } \\
54,00<\bar{X} \leq 72,00=\text { rendah } \\
27,00<\bar{X} \leq 54,00=\text { sangat rendah }
\end{gathered}
$$

Hasil penelitian diperoleh skor tertinggi 134, skor terendah 81, simpangan baku 14,01 dan rata-rata skor kedisiplinan siswa sebesar 110,08 berada dalam interval $108,00<\overline{\mathrm{X}} \leq 135,00$. Dengan demikian, dapat disimpulkan bahwa kecenderungan kedisiplinan siswa kelas XI SMA se-Kecamatan Ngampilan termasuk kategori sangat tinggi.

d. Prestasi Belajar Fisika (Y)

Berdasarkan tes prestasi belajar fisika yang diberikan kepada siswa kelas XI semester 2 SMA Se-Kecamatan Ngampilan, diperoleh data dengan menjumlahkan skor dari tes prestasi belajar. Namun, setelah diidentifikasi dari 30 butir soal tersebut 27 butir sahih dan 3 butir gugur dengan skala penilaian benar skor 1 dan salah skor 0 diperoleh, Skor maksimum ideal $=27 \times 1=27$, Skor minimal ideal $=27 \times 0=0$, $\mathrm{M}_{\text {ideal }}=0,5 \times(27+0)=13,5, \mathrm{SD}_{\text {ideal }}=0,167 \times(27-0)=4,509$. Berdasarkan nilai rata-rata ideal dan standar deviasi ideal diperoleh kriteria umum kurva normalnya sebagai berikut.

$$
\begin{aligned}
20,26<\bar{X} \leq 27,00 & =\text { sangat tinggi } \\
15,75<\bar{X} \leq 20,26 & =\text { tinggi } \\
11,24<\bar{X} \leq 15,75 & =\text { sedang } \\
6,73<\bar{X} \leq 11,24 & =\text { rendah } \\
0,00<\bar{X} \leq 6,73 & =\text { sangat rendah }
\end{aligned}
$$


Hasil penelitian diperoleh skor tertinggi 27, skor terendah 6, simpangan baku 5,18 danrata-rata skor prestasi belajar fisika sebesar 18,46 berada dalam interval $15,75<\bar{X} \leq 20,26$. Dengan demikian, dapat disimpulkan bahwa kecenderungan prestasi belajar fisika siswa kelas XI SMA se-Kecamatan Ngampilan termasuk kategori tinggi.

3. Uji Asumsi

a. Uji Normalitas Sebaran

Hasil analisis uji normalitas sebaran rangkuman hasil perhitungan di atas disajikan pada tabel berikut.

Tabel 1. Rangkuman Hasil Uji Normalitas Sebaran

\begin{tabular}{|l|l|c|c|c|}
\hline No & \multicolumn{1}{|c|}{ Variabel } & $\boldsymbol{\chi}_{\text {hitung }}^{\mathbf{p}}$ & $\mathbf{p}$ & Kesimpulan \\
\hline 1 & Gaya Belajar Siswa & 12,070 & 0,148 & Normal \\
\hline 2 & Kondisi Ekonomi Keluarga & 4,604 & 0,867 & Normal \\
\hline 3 & Kedisiplinan Siswa & 15,779 & 0,072 & Normal \\
\hline 4 & Prestasi Belajar Fisika & 11,126 & 0,195 & Normal \\
\hline
\end{tabular}

b. Uji Linieritas Hubungan

Hasil perhitungan uji linieritas hubungan variabel $\mathrm{X}$ dengan $\mathrm{Y}$ di atas dapat dirangkum pada tabel sebagai berikut.

Tabel 2. Rangkuman Hasil Uji Linieritas Hubungan

\begin{tabular}{|l|l|l|l|l|}
\hline No & \multicolumn{1}{|c|}{ Variabel Bebas $(\mathbf{X})$} & F $_{\text {hitung }}$ & \multicolumn{1}{|c|}{$\mathbf{P}$} & \multicolumn{1}{|c|}{ Kesimpulan } \\
\hline 1 & Gaya Belajar Siswa & 0,774 & 0,615 & Linier \\
\hline 2 & Kondisi Ekonomi Keluarga & 0,314 & 0,583 & Linier \\
\hline 3 & Kedisiplinan Siswa & 0,890 & 0,650 & Linier \\
\hline
\end{tabular}

4. Hasil Pengujian Hipotesis

Pengujian hipotesis ini terdiri dari dua macam hipotesis yaitu hipotesis mayor dan hipotesis minor.

a. Hipotesis Mayor

Hasil perhitungan analisis regresi ganda, maka dapat dilihat pada rangkuman tabel berikut.

Tabel 3. Hasil perhitungan Analisis Regresi Ganda

\begin{tabular}{|c|c|c|c|c|c|c|}
\hline $\begin{array}{c}\text { Sumber } \\
\text { Variasi }\end{array}$ & db & JK & RK & $\mathbf{F}_{\text {hitung }}$ & $\mathbf{P}$ & Keterangan \\
\hline Regresi & 3 & $1.111,194$ & $\begin{array}{l}370,39 \\
8\end{array}$ & \multirow[t]{2}{*}{25,995} & \multirow[t]{2}{*}{0,000} & \multirow{3}{*}{$\begin{array}{c}\text { Sangat } \\
\text { Signifikan }\end{array}$} \\
\hline Residu & 82 & $1.170,201$ & 14,271 & & & \\
\hline Total & 85 & $2.281,395$ & & & & \\
\hline
\end{tabular}


b. Hipotesis Minor

Hasil perhitungan statistik analisis korelasi parsial dari ketiga hipotesis minor, maka dapat dilihat pada rangkuman tabel sebagai berikut.

Tabel 4. Hasil perhitungan Analisis Korelasi Parsial

\begin{tabular}{|l|c|c|c|c|c|}
\hline No & Prediktor & $\mathbf{r}_{\text {parsial }}$ & $\mathbf{t}_{\text {hitung }}$ & $\mathbf{P}$ & Keterangan \\
\hline 1 & $\begin{array}{c}\text { Gaya Belajar } \\
\text { Siswa }\end{array}$ & 0,336 & 3,231 & 0,002 & Sangat Signifikan \\
\hline 2 & $\begin{array}{c}\text { Kondisi Ekonomi } \\
\text { Keluarga }\end{array}$ & 0,250 & 2,337 & 0,021 & Signifikan \\
\hline 3 & $\begin{array}{c}\text { Kedisiplinan } \\
\text { Siswa }\end{array}$ & 0,594 & 6,683 & 0,000 & Sangat Signifikan \\
\hline
\end{tabular}

Gaya belajar merupakan cara yang digunakan siswa dalam memahami materi pembelajaran khususnya fisika. Berkenaan dengan gaya belajar setiap siswa berbeda-beda, maka selaku pengajar seyogianya mengetahui gaya belajar para siswanya, sehingga dapat memilih dan menggunakan metode pembelajaran yang cocok dan disenangi siswanya. Untuk mengetahui jenis gaya belajar siswa tersebut, guru dapat membuat angket gaya belajar serta mengolahnya untuk mengetahui kecenderungan gaya belajar siswa tersebut (Sundayana, 2016: 77-78). Jika siswa mengetahui gaya belajar mana yang sesuai dengan karakternya maka siswa tersebut dapat dengan mudah untuk memahami maupun menangkap materi pembelajaran yang diberikan dengan baik. Sehingga, dapat memudahkan siswa dalam belajar sesuai dengan gaya belajarnya masing-masing.

Ketika kita telah mengetahui gaya belajar mana yang sesuai maka kondisi ekonomi keluarga pun turut berperan penting dalam mengembangkan karakter anak dalam belajar. Kondisi ekonomi keluarga adalah keadaan dimana keluarga itu dapat bekerja dan menghasilkan pendapatan sehingga dapat memenuhi hidupnya (Rusnaini, 2013: 88). Apabila keluarga yang mempunyai penghasilan relatif rendah pada umumnya mengalami kesulitan dalam pembiayaan sekolah, begitu juga dengan keperluan lainnya. Hal ini dapat menurunkan semangat anak untuk belajar. Berbeda dengan kondisi ekonomi keluarga tergolong cukup atau tinggi pada umumnya akan lebih mudah memenuhi segala kebutuhan sekolah dan keperluan lain sehingga anak akan termotivasi dalam belajar. Sehingga, kemampuan yang siswa miliki dapat tersalurkan dengan baik sesuai dengan bidang dan gaya belajarnya.

Siswa yang kemampuannya tersalurkan dengan baik maka akan menumbuhkan keinginan semangat yang tinggi untuk giat belajar maupun berlatih. Pendapat lain diungkapkan oleh Haryono, S (2016: 264) bahwa Disiplin mengandung arti adanya kesediaan untuk mematuhi peraturan-peraturan yang berlaku. Kepatuhan disini bukan hanya karena adanya tekanan-tekanan dari luar, melainkan kepatuhan yang didasari oleh adanya kesadaran tentang nilai dan pentingnya peraturan-peraturan. Sehingga, dengan hal tersebut berpengaruh terhadap siswa pada berbagai aturan yang ditetapkan oleh sekolah serta aktif dalam mengikuti kegiatan pembelajaran di kelas. Dengan demikian, dapat 
menumbuhkan kesadaran untuk disiplin di sekolah, dan akhirnya akan berpengaruh pada peningkatan prestasi belajarnya yang maksimal. Prestasi belajar adalah kemampuan dan penguasaan pengetahuan yang dimiliki siswa dalam kegiatan belajar yang diukur dan dinilai dalam bentuk nilai akhir (Daud, Maimunah H \& Lidi, Maria W., 2020: 147)

\section{PENUTUP}

\section{Secara Deskriptif}

a. Kecenderungan gaya belajar siswa kelas XI SMA Se-Kecamatan Ngampilan dalam kategori tinggi.

b. Kecenderungan kondisi ekonomi keluarga kelas XI SMA Se-Kecamatan Ngampilan dalam kategori sedang.

c. Kecenderungan kedisiplinan siswa kelas XI SMA Se-Kecamatan Ngampilan dalam kategori sangat tinggi.

d. Kecenderungan prestasi belajar fisika siswa kelas XI SMA Se-Kecamatan Ngampilan dalam kategori tinggi.

2. Secara Korelatif

a. Ada korelasi yang positif dan sangat signifikan antara gaya belajar siswa, kondisi ekonomi keluarga dan kedisiplinan siswa dengan prestasi belajar fisika siswa kelas XI SMA Se-Kecamatan Ngampilan.

b. Ada korelasi yang positif dan sangat signifikan antara gaya belajar siswa dengan prestasi belajar fisika siswa kelas XI SMA Se-Kecamatan Ngampilan.

c. Ada korelasi yang positif dan signifikan antara kondisi ekonomi keluarga dengan prestasi belajar fisika siswa kelas XI SMA Se-Kecamatan Ngampilan.

d. Ada korelasi yang positif dan sangat signifikan antara kedisiplinan siswa dengan prestasi belajar fisika siswa kelas XI SMA Se-Kecamatan Ngampilan.

\section{UCAPAN TERIMAKASIH}

Ucapan terimakasih ditujukan kepada Ketua STMIK PPKIA Tarakanita Rahmawati Tarakan, Kepala Program Studi Sistem Informasi, Tim Jurnal Optika Uniflor, kepala SMA se-Kecamatan Ngampilan dan segenap para dewan dosen, staf yang tidak dapat disebutkan semuanya.

\section{DAFTAR PUSTAKA}

Anas Sudijono. (2012). Pengantar Statistik Pendidikan. Jakarta: PT Raja Grafindo Persada.

Conny R. Semiawan. (2008). Penerapan Pembelajaran Pada Anak. Jakarta: PT Indeks.

Desmita. (2012). Psikologi Perkembangan Peserta Didik. Bandung: PT Remaja Rosdakarya.

Daud, Maimunah H \& Lidi, Maria W. (2020). Hubungan Kebiasaan Belajar dan Minat Belajar dengan Prestasi Belajar IPA Siswa SMPK St. Gabriel Ndona. Optika Jurnal 
$\begin{array}{llllllll}\text { Pendidikan Fisika. } & \text { Vol. } & \text { 4, No. } & \text { 2, } & 147 & \text { Januari }\end{array}$

DOI: https://doi.org/10.37478/optika.v4i2.725

Effendi, Mursilah \& Mujiono. (2018). Korelasi Tingkat Perhatian Orang Tua dan Kemandirian Belajar dengan Prestasi Belajar Siswa. Jurnal Ilmiah Multi Sciences.

Vol. 10 (1), 17-23 Januari 2018 DOI: https://doi.org/10.30599/jti.v10i1.131

Haryono, S. (2016). Pengaruh Kedisiplinan Siswa Dan Motivasi Belajar Terhadap Prestasi Belajar Siswa Pada Mata Pelajaran Ekonomi Di SMA Swasta Depok. Jurnal Ilmiah Kependidikan. Vol. 3 No. 3, 261-274 November 2016,doi: http://dx.doi.org/10.30998/.v3i3.939

Mulyasa, E. (2008). Implementasi Kurikulum Tingkat Satuan Pendidikan Kemandirian Guru dan Kepala Sekolah. Jakarta: PT Bumi Aksara.

Nana, Syaodih Sukmadinata. (2003). Landasan Psikologi Proses Pendidikan. Bandung: PT Remaja Rosdakarya.

Nini Subini, DKK. (2012). Psikologi Pembelajaran. Yogyakarta: MentariPustaka.

Rusnaini. (2013). Pengaruh Kondisi Ekonomi Keluarga terhadap Tingkat Keaktifan Anak Masuk Sekolah di SDN Pinggir Papas 1 Kecamatan Kalianget. Jurnal Performance Bisnis \& Akuntansi. Vol. 3 No.2, 88.

Slameto. (2003). Belajar dan faktor-faktor yang mempengaruhinya. Jakarta: PT Rineka Cipta.

Sugiyono. (2007). Statistika Untuk Penelitian. Bandung: Alfabeta.

Sugiyono. (2010). Metode Penelitian Pendidikan. Bandung: Alfabeta.

Suharsimi, Arikunto. (2010). Prosedur Penelitian Suatu Pendekatan Praktik Edisi 2010. Jakarta: PT Rineka Cipta.

Sundayana, R. (2016). Kaitan antara Gaya Belajar, Kemandirian Belajar, dan Kemampuan Pemecahan Masalah Siswa SMP dalam Pelajaran Matematika. Jurnal Pendidikan Matematika STKIP Garut. Vol. 5 No. 2, 75 - 84 Mei 2016 doi: https://doi.org/10.31980/mosharafa.v5i2.262

Zainal, Arifin. (2012). Evaluasi Pembelajaran. Bandung: PT Remaja Rosdakarya.

Wirantasa, U. (2017). Pengaruh Kedisiplinan Siswa terhadap Prestasi Belajar Matematika. Jurnal Formatif Vol. 7 (1) 83-95 Online: https://journal.lppmunindra.ac.id/index.php/Formatif/article/view/1272 